\title{
Osvetlitev rabe velike oz. male začetnice pri izlastnoimenskih pridevnikih s priponskimi obrazili -ov/-ev, -in v slovenščini
}

\begin{abstract}
Nataša Jakop
V trenutno veljavnem pravopisnem slovarju, sodobnih jezikovnih priročnikih in jezikovni rabi se srečujemo z mnogimi zapisovalnimi dvojnicami pri izlastnoimenskih pridevnikih s priponskimi obrazili -ov/-ev, -in, zlasti kadar so del stalnih besednih zvez in frazemov. Raba velike oziroma male začetnice pri izlastnoimenskih pridevnikih v slovenščini zato spada v skupino pravopisno problematičnih besed, ki naj bi bile v jezikovnih priročnikih in slovarjih ustrezno obravnavane, pojasnjene in ponazorjene. S prispevkom želimo opozoriti tudi na dejstvo, da je pri sodobnem normiranju izlastnoimenskih pridevnikov treba ponovno preučiti vse dejavnike, ki določajo njihovo jezikovno normo.

\section{Capitalized and Non-Capitalized Slovenian Adjectives Formed from Proper Nouns with the Suffixes -ov/-ev and -in}

The current Slovenian normative guide, modern language guides, and language use contain many spelling doublets for adjectives formed from proper names with the suffixes - ov/-ev and -in, especially when these are parts of fixed multi-word expressions and idioms. Capitalizing or not capitalizing Slovenian adjectives formed from proper names is therefore a problematic normative lexical issue that should be suitable dealt with, clarified, and exemplified in language guides and dictionaries. This article seeks to highlight the fact that current efforts to standardize adjectives formed from proper names require a new examination of all factors that define their linguistic norm.
\end{abstract}

\section{Uvodna pojasnila}

$\mathrm{V}$ prispevku je osvetljena sodobna problematika ene od pravopisno težjih skupin besed, tj. raba velike oz. male začetnice pri izlastnoimenskih pridevnikih s priponskimi obrazili -ov/-ev, -in v stalnih besednih zvezah in frazemih, zato naj uvodoma pojasnimo, kaj zajame pojem izlastnoimenskih pridevnikov.

Termin »svojilni pridevniki«, ki ga ob problemu zapisovanja velike in male začetnice uporabljajo slovenski pravopisi od Levca dalje, je ob upoštevanju sodobnih jezikoslovnih spoznanj nenatančen, ker vprašanje rabe velike oz. male začetnice danes ne zajema le svojilnih, temveč tudi vrstne pridevnike, npr. Grahamov/grahamov kruh. Govoriti o »izsamostalniških pridevnikih« bi bilo vsekakor preširoko, saj bi s tem zajeli tudi pridevnike, ki za vprašanje rabe velike oz. male začetnice niso relevantni, npr. bezgov, lipov. Skupni lastnosti pridevnikov, pri katerih je raba 
velike oz. male začetnice lahko problematična, sta izlastnoimenska motivacija, torej izpeljava iz osebnega, stvarnega ali zemljepisnega lastnega imena, in priponsko obrazilo -ov/-ev oz. -in, npr. Abrahamov (< Abraham), Blažev (< Blaž), Ariadnin ( $<$ Ariadna); Mlinotestov ( $<$ Mlinotest), Mercatorjev ( $<$ Mercator), Murin ( $<$ Mura); Saturnov ( $<$ Saturn), Sončev ( $<$ Sonce), Zemljin ( $<$ Zemlja). Raba velike oz. male začetnice pri izlastnoimenskih pridevnikih s priponskimi obrazili -ski, -ovski/-evski, -anski sama po sebi ni problematična, npr. burbonski (< Burboni), alpski (< Alpe), harvardski (< Harvard); adamovski (< Adam), cankarjevski (< Cankar); cankarjanski (< Cankar), lahko pa postane, kadar so ti pridevniki del lastnega imena, npr. triglavski $\mathrm{v}$ zvezah, ki poimenujejo zemljepisno lastno ime, npr. Triglavska jezera, Triglavski narodni park, vendar ta vidik rabe velike oz. male začetnice ne bo predmet obravnave. $\mathrm{V}$ tem prispevku obravnavamo le rabo velike oz. male začetnice pri izlastnoimenskih pridevnikih na -ov/-ev, -in in ob tem opozarjamo še na termin »izlastnoimensko izrazje (Košmrlj - Levačič 1998), s katerim se označuje iz osebnih, zemljepisnih ali stvarnih lastnih imen nastalo eno- ali večbesedno strokovno izrazje, npr. tesla 'enota za gostoto magnetnega polja' $(<$ Nikola Tesla), apolon 'vrsta metulja' (< bog Apolon), Dopplerjev pojav (< Christian Doppler); andezit 'predornina' (< Andi), kanadska gos (< Kanada), triglavska roža (< Triglav); enciklopedisti (< Encyclopédie). ${ }^{1}$ Izlastnoimenski pridevniki so seveda lahko sestavina večbesednih strokovnih izrazov, kot je npr. pridevnik Dopplerjev v stalni besedni zvezi Dopplerjev pojav, vendar to ni edina možna raba izlastnoimenskih pridevnikov; lahko so tudi del prostih besednih zvez ali sestavine frazemov. Vse tri možnosti ponazarja iz osebnega lastnega imena izpeljani pridevnik Ahilov, ki je lahko del proste besedne zveze (Ahilov šcit), sestavina stalne besedne zveze (Ahilova kita 'kita, ki povezuje mečno mišico s petnico') ali frazema (Ahilova peta 'slabost, šibka točka').

Danes se v sodobnih jezikovnih priročnikih, slovarjih in jezikovni rabi srečujemo z mnogimi zapisovalnimi dvojnicami izlastnoimenskih pridevnikov na -ov/ $-e v,-i n$, zlasti to velja za pridevnike v stalnih besednih zvezah in frazemih. Izlastnoimenski pridevniki na -ov/-ev, -in so zato pravopisno problematična skupina besed, ki mora biti v jezikovnih priročnikih in slovarjih ustrezno obravnavana, pojasnjena in ponazorjena. $\mathrm{Ob}$ tem pa je pomembno tudi, da pri sodobnem normiranju ponovno preučimo vse dejavnike, ki določajo njihovo jezikovno normo.

\section{Iz zgodovine normiranja izlastnoimenskih pridevnikov}

Če se ozremo nazaj, vse do prvega slovenskega pravopisa, lahko ugotovimo, da je normiranje izlastnoimenskih pridevnikov na -ov/-ev, -in potekalo postopoma in vedno temeljilo na aktualnem jezikovnem gradivu. Sprva so pravopisna pravila zajela le pisanje izlastnoimenskih pridevnikov v prostih besednih zvezah, sčasoma pa je raznovrstno jezikovno gradivo, ki ga je prineslo tudi sistematično zbiranje zlasti za

${ }^{1}$ Zgledi so bili izbrani iz prispevka B. Košmrlj - Levačič (1998). 
potrebe izdelave razlagalnega slovarja slovenskega jezika, narekovalo natančnejšo sistematizacijo te jezikovne pojavnosti.

Pravopisna pravila v Levčevem (Levec 1899) in Breznikovem (Breznik 1920) pravopisu ter pravopisih iz leta 1935 (SP 1935) in 1950 (SP 1950) pričajo o tem, da so se do izdaje Slovenskega pravopisa 1962 (SP 1962) vsi iz lastnega imena izpeljani pridevniki na -ov/-ev, -in zapisovali z veliko, pridevniki na -ski, -ovski/-evski, -anski pa z malo začetnico, npr. Jurčičeva pisava : mohamedanska vera (Levec 1899: § 596, § 597), Cankarjev slog : savski valovi (Breznik 1920: $\S 13, \S 15)$, Cankarjev jezik : cankarski jezik (SP 1935: § 9), Vodnikov : salomonski (SP 1950: § 14). Ponazarjalni zgledi ob pravilu o zapisovanju izlastnoimenskih pridevnikov na -ov/-ev, -in so v omenjenih pravopisih zajeli pridevnike, ki izražajo svojino in so del prostih besednih zvez, npr. Levstikov slog (Levec 1899), Meškove črtice (Breznik 1920), Cankarjev jezik (SP 1935), Breznikova slovnica (SP 1950). $\mathrm{V}$ pravilih ne zasledimo posebnih napotkov za zapisovanje izlastnoimenskih pridevnikov v stalnih besednih zvezah in frazemih. Zanimalo nas je, kako so bili prikazani v posameznih slovarskih sestavkih. Iščoč zapis pridevnika na -ov/-ev, -in v (stalnih) besednih zvezah, smo pregledali črko A v vseh pravopisnih slovarjih: Levčev in Breznikov pravopis v slovarskem delu pri črki A nimata nobene (stalne) besedne zveze z izlastnoimenskim pridevnikom na -ov/-ev, -in, SP 1935 navaja eno samo zvezo, zapisano le z veliko začetnico (Adamovo jabolko), SP 1950 pa ponuja nekoliko več gradiva. Najdemo ga v iztočnicah naslednjih osebnih lastnih imen: Abraham, Adam, Ahil, Ajshil, Amor, Ampère, Amundsen, Antigona, Apolon, Arhimed, Ariadna, Aristofan, Aristotel, Avgij. Slovarski sestavki ob tem kažejo, da so se izlastnoimenski pridevniki na -ov/-ev, -in zapisovali z veliko začetnico ne glede na to, ali je bil pridevnik del proste besedne zveze in je ohranil svojilni pomen, npr. Ajshilove tragedije, ali pa je bil pridevnik sestavina frazema, v katerem je (že) izgubil svoj svojilni pomen, npr. Adamovo jabolko 'na vratu vidni ščitasti hrustanci pri odraslem moškem', Adamova obleka 'nagota', Adamovi potomci 'ljudje', Adamov sin 'slaboten, zmotljiv človek'. Frazemskost teh besednih zvez je v slovarju izpričana ravno $z$ danimi pomenskimi opisi. Takšno nakazovanje prenesenega pomena je postalo v pravopisnih slovarjih tradicionalno in se je ohranilo vse do danes. Izlastnoimenski pridevniki, ki niso svojilni, imajo v SP 1950 priponsko obrazilo -ski, -ovski/-evski, -anski; ti so se brez izjeme zapisovali z malo začetnico, npr. ajhilska zamerljivost (v iztočnici Ajshil), amperska ura (v iztočnici Ampère), aristofanska šala (v iztočnici Aristofan).

Za prvo obdobje normiranja izlastnoimenskih pridevnikov lahko sklenemo, da je raba velike oz. male začetnice sledila jezikoslovnemu ločevanju med »svojilnimi pridevniki od lastnih imen« in »pridevniki osebnih imen, ki niso svojilni« (SP 1950: § 14); med seboj pa so se ti pridevniki ločevali po različnih priponskih obrazilih. To protistavno razmerje je bilo prikazano tudi v slovarskem delu pravopisa; v SP 1950 v okviru lastnoimenskih iztočnic, npr. Ajshilova resnost : ajshilsko vzvišen (v iztočnici Ajshil); Ampèrov zakon, Ampèrovo pravilo : amperska ura (v iztočnici Ampère), Aristofanova satira : aristofanska šola (v iztočnici Aristofan). Zaradi pisanja vseh izlastnoimenskih pridevnikov na -ov/-ev, -in z veliko začetnico 
pa jezikovni uporabniki v tem obdobju najverjetneje niso imeli posebnih težav pri zapisovanju.

Rahel odmik od do takrat doslednega zapisovanja izlastnoimenskih pridevnikov na -ov/-ev, -in z veliko začetnico je mogoče opaziti v SP 1962, v katerem je prišlo do minimalnega, a pomembnega preoblikovanja pravila o pisanju »svojilnih pridevnikov od lastnih imen na -ov -ova -ovo (-ev -eva -evo) ali -in -ina -ino« (SP 1962: $\S 37,6$. točka). ${ }^{2}$ Novo pravilo je poleg že ustaljenega pisanja izlastnoimenskih pridevnikov $\mathrm{z}$ veliko začetnico dopuščalo, da »svojilne pridevnike v rastlinskih in podobnih imenih pišemo lahko tudi z malo začetnico: salomonov pečat, marijini laski ipd.« (SP 1962: § 37, 6. točka). Novi predpis lahko razumemo kot prvi poskus normiranja izlastnoimenskega pridevnika na -ov/-ev, -in, kadar je ta del stalnih besednih zvez, čeprav to v pravilu ni bilo izrecno izpostavljeno. Kljub temu da novo pravilo ni predpisovalo, temveč dovoljevalo rabo male začetnice $\mathrm{v}$ rastlinskih poimenovanjih, je bil $\mathrm{v}$ slovarskem delu pravopisa $\mathrm{v}$ teh primerih prikazan le zapis z malo začetnico. Spremembo v predpisu, ki je verjetno vplivala tudi na nadaljnje pisanje drugih pomenskih skupin izlastnoimenskih pridevnikov na $-o v /-e v,-i n$, je mogoče razlagati kot posledico takratne jezikovne rabe. SP 1962 je namreč pri normiranju slonel na »splošni rabi v pisanju« (Bajec 1961/62: 13), zato sklepamo, da je v petdesetih letih pri rastlinskih imenih, izpeljanih iz lastnega imena, prevladovala raba male začetnice. To je mogoče preveriti v jezikovnem gradivu Inštituta za slovenski jezik Frana Ramovša ZRC SAZU, ki je bilo osnovni vir tudi za takratni pravopisni slovar (Bajec 1961/62: 13). Gradivo pri izlastnoimenskem pridevniku Salomonov res izpričuje prevladujočo rabo male začetnice pridevnika v stalni besedni zvezi, ki poimenuje rastlino (salomonov pečat), bolj nedosledna pa je bila raba velike oz. male začetnice $\mathrm{v}$ stalnih besednih zvezah pri pridevniku Marijin. Dvojnice, pri čemer prevladujejo zapisi z veliko začetnico, so obstajale pri posameznih rastlinskih poimenovanjih (Marijini/marijini laski, Marijini/marijini lasci, Marijine/marijine solze), vendar ne pri vseh (Marijini rokavci, Marijin osat, Marijini čeveljčki, Marijini šolenčki). Dvojnična raba je izpričana tudi v nekaterih drugih stalnih besednih zvezah, npr. za poimenovanje vrste kristala (Marijino/marijino steklo) in krščanski praznik na 25. $\operatorname{marec}^{3}$ (Marijino/marijino oznanjenje).

Ne da bi se spuščali v vsak primer posebej, je ob gradivu iz petdesetih in šestdesetih let 20. stoletja mogoče opaziti pojavljanje neenotne rabe velike oz. male začetnice izlastnoimenskih pridevnikov na -ov/-ev, -in $\mathrm{v}$ posameznih pomenskih skupinah stalnih besednih zvez, medtem ko se $\mathrm{v}$ frazemih $\mathrm{v}$ glavnem potrjuje raba velike začetnice, npr. Abrahamova leta, biti v Adamovem kostumu, Adamovo jabolko (po letu 1962 tudi z malo začetnico), Ahilova peta (po letu 1971 tudi z malo začetnico), Ariadnina nit. Kot kažejo slovarski sestavki v SP 1962, je tem smernicam sledila tudi jezikovna norma, saj so se ti pridevniki zapisovali le z veliko začetnico, npr. $v$ Abrahamovem naročju 'na onem svetu' (v iztočnici Abraham), Adamova

2 SP 1962 je bil predelana in izpopolnjena izdaja pravopisa iz leta 1950 (prim. SP 1962: 5; Bajec 1961/62: 13).

3 Zanimivo je, da zapisi za poimenovanje krščanskega praznika na 15. avgust (Marijino vnebovzetje) potrjujejo le rabo velike začetnice. 
obleka 'nagota' (v iztočnici Adam). ${ }^{4} \mathrm{Z}$ veliko začetnico so v SP 1962 normirani tudi vsi izlastnoimenski pridevniki na -ov/-ev, -in v stalnih besednih zvezah, ki poimenujejo duhovno lastnino, npr. Ampèrjev zakon (v iztočnici Ampèr), Arhimedova spirala (v iztočnici Arhimed), Aristotelova šola (v iztočnici Aristotel), Avogadrovo število (v iztočnici Avogadro). Razen redkih izjem, ki imajo v gradivu potrditve tudi za rabo male začetnice, npr. Dieslov/dieslov/dizlov motor, Kolomonov/kolomonov žegen, Priolov/priolov delišes, so se izlastnoimenski pridevniki na -ov/-ev, -in v stalnih besednih zvezah v tem obdobju zapisovali le z veliko začetnico, npr. Arhimedov zakon, Avogadrovo število, kolo Francisove turbine, Ottov motor, Rubikova kocka.

Jezikovni dokument, ki izpričuje nove smernice rabe velike oz. male začetnice pri izlastnoimenskih pridevnikih v stalnih besednih zvezah in frazemih po SP 1962, je Slovar slovenskega knjižnega jezika (SSKJ 1-5). SSKJ se je pri normiranju leksike naslanjal na tradicijo in hkrati upošteval spremembe v jezikovni rabi, kot jih je potrjevalo gradivo in opravljene ankete (SSKJ 1: XI, § 8). Statistično gledano je v SSKJ od 60 izlastnoimenskih pridevniških iztočnic s priponskim obrazilom -ov pri 10 pridevnikih, ki so sestavine stalnih besednih zvez ali frazemov, normirana dvojnica z malo začetnico: Adamovo/adamovo jabolko, Francisovalfrancisova turbina, Kaplanova/kaplanova turbina, nedolžen, reven kot Lahov/lahov koš, Ottov/ottov motor, Peltonova/peltonova turbina, Priolov/priolov delišes, Rubikova/rubikova kocka, Wassermannova/wassermannova reakcija, Zoisova/zoisova zvončica. Od 21 izlastnoimenskih pridevniških iztočnic s priponskim obrazilom -ev je dvojnični zapis z malo začetnico normiran pri 3 pridevnikih: Elijev/elijev ogenj, Tomaževal tomaževa žlindra, Žnideršičev/žnideršičev panj, medtem ko so vse 4 izlastnoimenske pridevniške iztočnice s priponskim obrazilom -in v stalnih besednih zvezah in frazemih normirane le z veliko začetnico, npr. Marijino oznanjenje, Ariadnina nit. $\mathrm{Z}$ malo začetnico so v SSKJ normirane nekatere redke stalne besedne zveze, ki poimenujejo duhovno lastnino, izume, stvaritve: bergmanova cev ( $<$ Bergmann), burova tableta, burova voda (< Burow), ${ }^{5}$ dizlov/dieslov motor $(<\mathrm{Diesel})$, knajpova kava ( $<$ Kneipp), kolomonov žegen ( $<$ Kolomon). Pri teh pridevnikih je izlastnoimenska motivacija že precej zakrita bodisi zaradi manj znane osebnosti, ki je povezana $\mathrm{z}$ izumom (npr. kirurg Karel August Burow), bodisi zaradi podomačevanja izrazne podobe izlastnoimenskega pridevnika (dieslov : dizlov) ali iz skupka več dejavnikov, ki so spodbudili zapis z malo začetnico. V skladu s pravilom v SP 1962, ne pa vedno tudi v skladu s takratno jezikovno rabo, so v SSKJ z malo začetnico normirane stalne besedne zveze, ki poimenujejo rastline. npr. judeževo drevo (< Judež), kristusov grm (< Kristus), marijini laski (< Marija), salomonov pečat ( $<$ Salomon), venerini lasci (< Venera), z redkimi izjemami, npr. Zoisova/zoisova zvončnica, Blagajev volčin, Sprengerjev beluš. Le z malo začetnico so normirane tudi školjke

4 Pri besednih zvezah Ahilova peta (v geslu Ahil), Amorjeva puščica (v geslu Amor), Ariadnina nit (v geslu Ariadna) bi teoretično lahko šlo tudi za svojilni pridevnik v prosti besedni zvezi, ne za frazeološko zvezo, ker slovar ob teh primerih ne navaja metaforičnega pomenskega prenosa; vendar je to malo verjetno.

5 Pustimo ob strani nesistemsko tvorbo tega izlastnoimenskega pridevnika. 
oz. morske živali, npr. noetova barčica $(<$ Noe), venerin pas $(<$ Venera), nekatera poimenovanja delov telesa, npr. venerin griček $(<$ Venera), in le izjemoma frazemi, npr. blažev žegen (< Blaž).

Iz povedanega je mogoče povzeti, da so bili v SSKJ izlastnoimenski pridevniki na -ov/-ev, -in $\mathrm{v}$ stalnih besednih zvezah in frazemih razen redkih izjem prednostno normirani z veliko začetnico. V vmesnem obdobju med izidom SSKJ in SP 2001 se je moralo zgoditi nekaj prelomnega, saj slovarski del zadnjega pravopisa potrjuje obstoj velikega števila novih dvojnic, mnogih celo prednostno normiranih z malo začetnico. Zadnji in trenutno veljavni Slovenski pravopis (SP 2001, 2003) izpričuje veliko razširitev pomenskih skupin pri rabi male začetnice izlastnoimenskih pridevnikov na -ov/-ev, -in ne le pri rastlinah, temveč tudi pri poimenovanjih za duhovno last (pitagorov/Pitagorov izrek), kulturno tematiko (ahilova/Ahilova peta), bolezni (parkinsonova/Parkinsonova bolezen), dele telesa (adamovo/Adamovo jabolko) in izume (papinov/Papinov lonec) ${ }^{6}$ Okoliščine, ki so vplivale na spremembe $\mathrm{v}$ predpisu, bomo skušali osvetliti v nadaljevanju.

\section{Vpliv jezikoslovne kategorizacije izlastnoimenskih pridevnikov na predpis}

Sestavljavci novih pravopisnih pravil po SP 1962 so pri kategorizaciji pomenskih skupin izlastnoimenskih pridevnikov, ki naj bi se zapisovali (tudi) z malo začetnico, upoštevali novo jezikoslovno spoznanje, da iz osebnih lastnih imen tvorjeni pridevniki s priponskimi obrazili -ov/-ev, -in ne izražajo samo svojilnosti, temveč tudi druge pomene. ${ }^{7} \mathrm{O}$ tem priča odgovor avtorjev osnutka novih pravil J. Toporišiča in J. Riglerja na kritike B. Urbančiča (1978), v katerem mu pojasnjujeta, da se izlastnoimenski pridevniki $\mathrm{v}$ imenih rastlin, bolezni, delih telesa, tehničnih izdelkih pišejo z malo, ker niso svojilni, temveč vrstni (Toporišič - Rigler 1978: 221).

$\mathrm{V}$ osnutku novega pravila se raba velike začetnice omejuje le na tiste stalne besedne zveze, ki poimenujejo zakone in teorije, in frazeme s področja kulturne tematike. Pomenske skupine stalnih besednih zvez, v katerih naj bi se pridevnik na -ov/-ev, -in zapisoval z malo začetnico, so se v primerjavi s pravilom v SP 1962 bistveno razširile in so obsegale imena rastlin, bolezni, delov telesa in tehničnih izdelkov, npr. salomonov pečat, marijini laski, blagajev volčin, parkinsonova bolezen, adamovo jabolko, ahilova kita, evstahijeva cev, bergmanova cev, kaplanova turbina.

Novo pravopisno pravilo že med jezikoslovci ni bilo sprejeto z vsesplošnim odobravanjem in brez zadržkov. Pomisleke lahko razdelimo v tri skupine glede na

6 Pomenska področja z zgledi smo povzeli po H. Dobrovoljc (2004: 158).

7 To pomembno in prelomno spoznanje je v slovensko jezikoslovje prinesla A. Vidovič Muha s svojim magistrskim delom (Vidovič Muha 1977). Kasneje sta imela velik vpliv še dva njena prispevka, prvi o slovničnih merilih, po katerih je pridevniško besedo mogoče razvrstiti v posamezne pomenske skupine (Vidovič Muha 1978), in drugi o pomenski klasifikaciji nekakovostnih izpeljanih pridevnikov (Vidovič Muha 1981). 
to, ali so utemeljevali rabo velike oz. male začetnice s praktičnega (Urbančič), kulturološkega (B. Pogorelec, E. Kržišnik) ali strogo jezikoslovnega vidika (Toporišič, Rigler, A. Vidovič Muha).

B. Urbančič (1978) je že pred izidom Načrta kritiziral Toporišičev in Riglerjev Komentar k načrtu pravil slovenskega pravopisa (1977) in v kritiki ostro nasprotoval pravopisnemu pravilu, po katerem naj bi se »svojilni pridevniki« iz lastnih imen v poimenovanjih rastlin, bolezni, delov telesa, tehničnih izdelkov ipd. pisali z malo začetnico, z veliko pa le poimenovanja zakonov in teorij ter frazemi iz mitologije. Urbančiču se je zdelo nedopustno »begati ljudi z neživljenjskimi določili, po katerih naj bi take pridevnike v nekaterih zvezah pisali z malo, v drugih pa Z véliko začetnico« (Urbančič 1978: 86). Zagovarjal je stališče, da je pri tem pravopisnem vprašanju vsekakor treba upoštevati tudi laičnega jezikovnega uporabnika, zato se je zavzemal za rabo velike začetnice z redkimi izjemami, kot sta npr. blažev žegen, marijini laski, pri katerih je »pomen svojilnosti močno oslabljen in se je v rabi uveljavilo pisanje z malo« (Urbančič 1978: 86).

B. Pogorelec (1982) in E. Kržišnik (1982) sta v svojih pripombah k Načrtu pravil za novi pravopis spomnili na kulturološko rabo velike začetnice v slovenskem jeziku in zagovarjali prednostno upoštevanje tega vidika pri normiranju velike oz. male začetnice v stalnih besednih zvezah, katerih sestavina je izlastnoimenski pridevnik na -ov/-ev, -in. B. Pogorelec je v primerih tipa Blagajev volčin utemeljevala veliko začetnico s stališčem, da »[k]onverzija iz osebnih v vrstna imena [...] ne bi smela pomeniti tudi izgube pomenske prvine spoštljivega razmerja do osebe, ki je povezana s predmetom«, in da je poleg razmerja lastno oz. vrstno ime treba upoštevati tudi »razmerje spoštovanja do kulturnega izročila in kulturne ustvarjalnosti« (Pogorelec 1982: 69-70). E. Kržišnik (1982: 43) je ob tem pravilu izpostavila težave pri razmejevanju »[t. i.] kulturne tematike, ki naj bi narekovala pisavo z veliko začetnico«, in opozorila, da so navedeni zgledi omejeni le na kulturo iz grške mitologije. Vprašanja o tem, kaj kulturna tematika sploh je, zakaj naj zoisova zvončica ne bi spadala na področje kulturne tematike in po katerem od načel je Načrt pravil (1981) normiral pisanje zakonov, teorij in frazemov iz kulturne tematike z veliko začetnico, je E. Kržišnik (1992/93: 2003) izpostavila kasneje še enkrat in v kritiki spomnila na dejstvo, da se izrazi spoštovanja v slovenščini pišejo z veliko začetnico.

A. Vidovič Muha (1982) je opozorila, da je novi predpis glede velike oz. male začetnice pri pridevnikih na -ov/-ev, -in nedosleden in da je v nekaterih zgledih začetnica neustrezna, kar naj bi bila posledica »včasih nejasn[ega] razmejevanj[a] svojilnega, vrstnega in deloma kakovostnega pomena« (Vidovič Muha 1982: 122). Problematizirala je primere, kot npr. sizifovo delo, kjer gre za »konverzne kakovostne pridevnike«, in za ta tip frazemov predlagala malo začetnico (Vidovič Muha 1982: 122-123). Dejstvu, da v teh primerih ne gre vedno za svojilni pridevnik, sestavljavca pravil J. Toporišič in J. Rigler pravzaprav nikoli nista oporekala, sta pa pojasnila, da je rabo velike začetnice $\mathrm{v}$ posameznih primerih narekovala tudi »drugačna pisna praksa«, torej tedanja jezikovna raba (Toporišič - Rigler 1978: 221). Ne ozirajoč se na pragmatični ali kulturološki vidik, je A. Vidovič Muha zagovarjala sistemsko kategorizacijo velike oz. male začetnice: velika začetnica naj 
bi se ohranila le $\mathrm{v}$ tistih primerih, ko ima tvorjeni pridevnik svojilni pomen, npr. Pitagorov izrek, medtem ko naj bi se raba male začetnice uveljavila $\mathrm{v} v$ seh primerih, ko ima tvorjeni pridevnik kakovostni ali vrstni pomen, npr. sizifovo delo, papinov lonec.

Nejezikoslovci, zlasti naravoslovci, so protestirali proti mali začetnici v rastlinskih imenih, izpeljanih iz osebnih lastnih imen. Še posebej kritičen je bil botanik T. Wraber (1982), ki je ohranjanje velike začetnice utemeljeval z dejstvom, da se te rastline dejansko imenujejo po osebah, npr. Blagayu (Blagayev volčin), Zoisu (Zoisova zvončica), Freyerju (Freyerjev osat), Hacquetu (Hacquetova medvejka), v nasprotju z zvezami kot marijini laski, kjer je »povezava z osebo le še posredna«, oziroma če se navežemo na pojasnilo E. Kržišnik, v tem primeru »ni znanega, individualiziranega referenta (Kržišnik 1992/93: 15). Wraber se je sicer strinjal z jezikoslovci, da pri imenih rastlin, izpeljanih iz lastnih imen, res ne gre za »pravo lastnino«, vendar je ob tem opozoril, da je za botanike bistvena ravno povezava rastline s konkretno osebo, zato je ob normiranju male začetnice izrazil bojazen pred sekundarnim podomačevanjem pridevnika, npr. iz zoisove zvončnice $\mathrm{v}$ cojzovo, iz freyerjevega osata $\mathrm{v}$ frajerjevega in iz hacquetove medvejke v akejevo, kar bi bilo »nekulturno, preveč poenostavljeno in manj določno« (Wraber 1982: 128). Ta bojazen pravzaprav ni bila neutemeljena, saj slovenski pravopis pri prevzetih občnih besedah razen redkih izjem teži in usmerja k pisnemu podomačevanju, medtem ko pisno podobo prevzetih osebnih lastnih imen $\mathrm{v}$ slovenščini načeloma ohranjamo (SP 2001: § 164, § 172). Potrditve, da se z malo začetnico pisani izlastnoimenski pridevniki sčasoma začnejo pisno podomačevati, s čimer se dejansko izgubi izlastnoimenska motivacija, najdemo že v SSKJ v primerih, kot so bergmanova cev, burova voda, dizlov motor, glavberjeva sol, knajpova kava, saherjeva torta.

Pravila v SP 1990 so kljub mnogim pomislekom in kritikam v prvi vrsti sledila jezikoslovnim argumentom za rabo velike oz. male začetnice in so prednostno predpisala malo začetnico pri »vrstnih pridevnikih na -ov/-ev, -in iz lastnih imen « (SP 2001: § 157-159), velika začetnica pa je ostala le pri »svojilnih pridevnikih iz besed, pisanih z veliko (SP 2001: § 115) oz. se dovoljuje le v zvezah, ki zaznamujejo »duhovno last«, in frazemih. Tako je bilo določeno v predpisu, $\mathrm{v}$ slovarskem delu pravopisa pa so izlastnoimenski pridevniki na -ov/-ev, -in prednostno vedno zapisani z malo začetnico ne glede na to, ali gre $\mathrm{v}$ besedni zvezi za vrstni ali svojilni pridevnik, npr. adams-stokesov/Adams-Stokesov sindrom, blagajev/Blagajev volčin, elektrin/Elektrin kompleks. Ob tem še toliko bolj izstopajo nekatere redke izjeme, ki so v slovarskem delu pravopisa normirane le z veliko začetnico, npr. Dow-Johnesov indeks, Gospodov dan. V tem kontekstu bi gotovo lahko problematizirali tudi pravilo o zapisovanju praznikov, ki se sicer pišejo z malo začetnico, z veliko pa le, če so izpeljani iz priimka, npr. Prešernov dan (SP 2001: § 150). Ta »izjema« je najverjetneje sledila kulturološkemu načelu izražanja spoštovanja do znane osebe. 


\section{$4 \quad$ Stanje $v$ jezikovni rabi danes}

$\mathrm{V}$ sodobnem slovenskem jeziku lahko spremljamo rabo velike in male začetnice $\mathrm{v}$ večmilijonskih elektronskih korpusih. $\mathrm{V}$ tem prispevku smo pisanje izlastnoimenskih pridevnikov na -ov/-ev, -in preverili v besedilnem korpusu Inštituta za slovenski jezik Frana Ramovša Nova beseda, ki je avgusta 2009 vseboval 240 milijonov besed. ${ }^{8}$

Za izhodišče analize smo izbrali pridevnik Ahilov, saj, kot smo že omenili, lahko nastopa kot del prostih besednih zvez ali pa je sestavina stalne besedne zveze oziroma frazema. Gradivo v korpusu ponuja 519 pojavitev različnih oblik izlastnoimenskega pridevnika Ahilov. ${ }^{9}$ Razmerje med veliko in malo začetnico nas je presenetilo. Ko odštejemo tiste primere rabe velike začetnice, ki sledijo končnemu ločilu ali so naslovi, in zapise izlastnoimenskega pridevnika s samimi velikimi črkami, ugotovimo, da je pridevnik Ahilov/ahilov v kar $53 \%$ zapisan z malo začetnico.

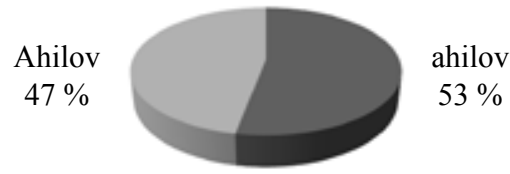

Slika 1: Razmerje velike in male začetnice pri pridevniku Ahilov/ahilov (vir: korpus Nova beseda)

V nadaljevanju smo bili pozorni na vlogo izlastnoimenskega pridevnika $v$ besednih zvezah in ob tem ugotovili, da so svojilni pridevniki v prostih besednih zvezah dosledno zapisani z veliko začetnico, npr. Ahilov govor, Ahilova mati, Ahilovo kljubovanje. Raba male začetnice je omejena le na stalno besedno zvezo ahilova tetiva $^{10}$ in frazem ahilova peta. Ti zvezi sta seveda zapisani tudi z veliko začetnico, kar pomeni, da je v sodobnem času pravopisno problematična le raba začetnice izlastnoimenskih pridevnikov na -ov/-ev, -in v stalnih besednih zvezah in frazemih. Razmerje $\mathrm{v}$ rabi male in velike začetnice $\mathrm{v}$ stalni besedi zvezi ahilova/Ahilova tetiva je opazno v prid mali začetnici ( $85 \%$ ), medtem ko je pri frazemu ahilovalAhilova peta ravno obratno $(14 \%) .{ }^{11}$

8 Korpus Nova beseda se vsako leto na novo ažurira in posodablja, zato omogoča neposreden vpogled $\mathrm{v}$ najaktualnejšo jezikovno rabo. To je za ugotavljanje in preverjanje jezikovne norme sodobne leksike zelo pomembno.

9 Izlastnoimenskemu pridevniku homonimno samostalniško obliko osebnega lastnega imena v imenovalniku ednine smo ob tem že izločili: Ženske dvojice - Dermastija, Todorovič : Baranova, Ahilov (Uzb).

${ }^{10}$ Presenetljivo je, da v korpusu ni nobene pojavitve sinonimne zveze Ahilovalahilova kita.

${ }^{11} \mathrm{~V}$ frazemu Ahilova peta smo pri zgledih z veliko začetnico preverili tudi, ali ne gre morda kdaj za rabo svojilnega pridevnika, in ugotovili, da je pridevnik Ahilov v zvezi Ahilova peta $\mathrm{v}$ tem gradivu vedno del frazema in $\mathrm{v}$ njem ne nastopa $\mathrm{v}$ svojem svojilnem pomenu. 
Ahilova tetiva

$15 \%$

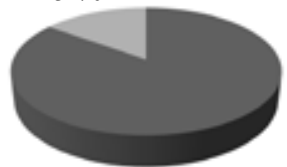

ahilova tetiva

$85 \%$

Slika 2: Razmerje velike in male začetnice v stalni besedni zvezi Ahilova/ahilova tetiva (vir: korpus Nova beseda)

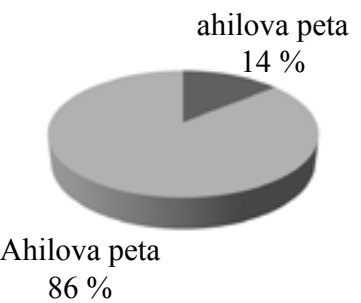

Slika 3: Razmerje velike in male začetnice v frazemu Ahilova/ahilova peta (vir: korpus Nova beseda)

Napačno bi bilo iz teh podatkov sklepati, da gre za trend zapisovanja izlastnoimenskega pridevnika $\mathrm{v}$ stalnih besednih zvezah $\mathrm{z}$ malo začetnico, $\mathrm{v}$ frazemih pa z veliko, saj se pridevniki v mnogih zvezah še vedno v pretežni meri zapisujejo le $\mathrm{z}$ veliko začetnico. Ob pregledu nekaterih drugih izlastnoimenskih pridevnikov v stalnih besednih zvezah in frazemih pa je vendarle mogoče ugotoviti neko smernico, tj. precej poljubno izbiro začetnice, ki ima navsezadnje podporo tudi v sedaj veljavnem akademijskem pravopisnem slovarju, kjer so izlastnoimenski pridevniki na -ov/-ev, -in večinoma dvojnično normirani.

$\mathrm{Na}$ tem mestu posredujemo le nekaj statističnih podatkov o trenutni rabi velike in male začetnice izlastnoimenskih pridevnikov: ${ }^{12}$ zveze Arhimedov zakon, Gaußova krivulja, Newtonov zakon, Pitagorov izrek, Ariadnina nit, Evin kostum/ kostim, Hipokratova prisega, Kristusova leta so zapisane le z veliko začetnico (100 \%). Pretežno z veliko začetnico se zapisujejo naslednje stalne besedne zveze in frazemi: Arhimedova točka (97 \%,), Sizifovo delo (92,8 \%), Parkinsonova bolezen (88,6 \%), Ojdipov kompleks (88,4 \%), Abrahamova leta (87,5\%), Alzheimerjeva bolezen (87,3\%), Machovo število (85,7\%), Kolumbovo jajce (80 \%), Zoisova zvončica (75\%), Avgijev hlev (72\%), Geigerjev števec (70,5%), Adamov kostum/

${ }^{12}$ Pri izračunu so bile upoštevane vse oblike posamezne zveze in izločeni zgledi, ki sledijo končnemu ločilu, so naslovi ali so zapisani s samimi velikimi črkami. 
kostim (69 \%) in Amorjeva puščica (62,5 \%). Pogostejšo rabo male začetnice izlastnoimenskih pridevnikov pa smo v pregledanem korpusnem gradivu zasledili v stalnih besednih zvezah arhimedova vijačnica $(100 \%),{ }^{13}$ blagajev volčin (82\%) in adamovo jabolko $(63 \%) .{ }^{14}$

\section{Sklepne ugotovitve in perspektivne rešitve}

Določanje jezikovne norme izlastnoimenskih pridevnikov s priponskimi obrazili -ov/-ev, -in je že od nekdaj temeljilo na gradivu jezikovne rabe. Raba izlastnoimenskih pridevnikov v preteklosti ni bila pravopisno problematična, saj so se njihovi svojilni pomeni od vrstnih ločevali tudi po različnih priponskih obrazilih, npr. Aristofanova satira : aristofanska šola. Do kasnejših sprememb v predpisu, ki so postopoma uvajale rabo male začetnice pri nekaterih pomenskih skupinah izlastnoimenskih pridevnikov na -ov/-ev, -in, je prišlo zaradi novih jezikoslovnih spoznanj. Sodobno jezikovno gradivo je preplavljeno $\mathrm{z}$ dvojnicami v rabi velike in male začetnice izlastnoimenskih pridevnikov na $-o v /-e v,-i n \mathrm{v}$ stalnih besednih zvezah in frazemih, kar je verjetno tudi neposredna posledica nekritično kategoriziranega jezikovnega gradiva v nazadnje izdanem pravopisnem slovarju. Eno od perspektivnih rešitev vidimo $\mathrm{v}$ ohranitvi tradicionalno že uveljavljenega nakazovanja prenesenih pomenov besednih zvez, katerih sestavina je izlastnoimenski pridevnik na -ov/-ev, -in, v pravopisnem slovarju. S tem se jezikovnemu uporabniku lahko ponazori ločevanje med rabo pridevnika $\mathrm{v}$ svojilnem pomenu in drugimi pomeni ter, posledično, rabo velike oziroma male začetnice.

Dolgoročno pa bi bilo v stroki vendarle smiselno spodbuditi razmišljanje o posodobitvi predpisa, pri čemer bi ob jezikoslovnem vidiku upoštevali vsaj še argumente kulturološke rabe velike začetnice v slovenščini.

\section{Viri in literatura}

Bajec 1961/62 = Anton Bajec, Pred izidom novega pravopisa, Jezik in slovstvo 7 (1961/62), št. 1, 103-118.

Breznik 1920 = Anton Breznik, Slovenski pravopis, Ljubljana: Jugoslovanska knjigarna, 1920.

Dobrovoljc 2004 = Helena Dobrovoljc, Pravopisje na Slovenskem, Ljubljana: Založba ZRC, ZRC SAZU (Lingua Slovenica).

${ }^{13}$ Gre pravzaprav le za dve pojavitvi.

${ }^{14}$ Podobno analizo stanja v jezikovni rabi je opravila že E. Kržišnik (2003: 232-233) na osnovi gradiva v korpusu Fida. Ugotovila je, da »se zgledi s prekategoriziranim svojilnim pridevnikom iz lastnega imena pišejo variantno, z veliko ali malo«, razmerje med veliko in malo začetnico pa gre v prid veliki začetnici, npr. Ahilova peta (67\%), Avgijev hlev $(100 \%)$, Ariadnina nit (100\%), Pirova zmaga (71 \%), Sizifovo delo (100\%), Talijin hram (100\%), Tantalove muke (100\%). 
Košmrlj - Levačič 1998 = Borislava Košmrlj - Levačič, Izimensko strokovno izrazje, v: Slovensko naravoslovno tehnično izrazje: Zbornik referatov s Posvetovanja o slovenskem naravoslovno-tehničnem izrazju, ur. Marjeta Humar, Ljubljana: Založba ZRC, 1998, 139-146.

Kržišnik 1982 = Erika Kržišnik, Načelne pripombe, pripombe k posameznim pravopisnim pravilom, popravki, v: Spoznanja in pripombe javne razprave o Načrtu pravil za novi pravopis, Ljubljana: Znanstveni inštitut Filozofske fakultete Univerze Edvarda Kardelja, 1982, 42-45.

Kržišnik 1992/93 = Erika Kržišnik, Pravopis v slovenski državi in slovenskem jezikoslovju, Slava: debatni list 6 (1992/93), št. 1, 8-17.

Kržišnik 2003 = Erika Kržišnik, Frazeologija v slovenskem pravopisu 2001, Slavistična revija 51 (2003), št. 2, 221-237.

Levec 1899 = Fran Levec, Slovenski pravopis, Dunaj: V cesarski kraljevi zalogi šolskih knjig, 1899.

Načrt pravil 1981 = Načrt pravil za novi slovenski pravopis, Ljubljana: Slovenska akademija znanosti in umetnosti, Inštitut za slovenski jezik (izd.) - Državna založba Slovenije (zal.), 1981.

Nova beseda $=$ Nova beseda : besedilni korpus, Inštitut za slovenski jezik Frana Ramovša ZRC SAZU (http://bos.zrc-sazu.si/s_beseda.html).

Pogorelec 1982 = Breda Pogorelec, Ob osnutku pravil slovenskega pravopisa, v: Spoznanja in pripombe javne razprave o Načrtu pravil za novi pravopis, Ljubljana: Znanstveni inštitut Filozofske fakultete Univerze Edvarda Kardelja, 1982, 59-71.

SP 1935 = Slovenski pravopis, Ljubljana: Znanstveno društvo, 1935.

SP 1950 = Slovenski pravopis, Ljubljana: Slovenska akademija znanosti in umetnosti, 1950.

SP 1962 = Slovenski pravopis, Ljubljana: Slovenska akademija znanosti in umetnosti, 1962.

SP 1990 = Slovenski pravopis 1: Pravila, Ljubljana: Slovenska akademija znanosti in umetnosti, Znanstvenoraziskovalni center SAZU, Inštitut za slovenski jezik Frana Ramovša (izd.) - DZS (zal.), 1990.

SP 2001 = Slovenski pravopis, Ljubljana: Slovenska akademija znanosti in umetnosti - Znanstvenoraziskovalni center SAZU, Inštitut za slovenski jezik Frana Ramovša (izd.) - Založba ZRC, ZRC SAZU (zal.), 2001.

SP 2003 = Slovenski pravopis, Ljubljana: Slovenska akademija znanosti in umetnosti - Znanstvenoraziskovalni center SAZU, Inštitut za slovenski jezik Frana Ramovša (izd.) - Založba ZRC, ZRC SAZU (zal.), 2003.

SSKJ 1-5 = Slovar slovenskega knjižnega jezika 1-5, Ljubljana: Slovenska akademija znanosti in umetnosti, 1970-1991.

Toporišič - Rigler 1977 = Komentar k Načrtu pravil slovenskega pravopisa, Slavistična revija 25 (1977), št. 2-3, 311-358.

Toporišič - Rigler 1978 = Jože Toporišič - Jakob Rigler, Ob Urbančičevi kritiki pravil SP, Slavistična revija 26 (1978), št. 2, 208-226.

Urbančič 1978 = Boris Urbančič, Nekaj pripomb k načrtu pravil slovenskega pravopisa, Slavistična revija 26 (1978), št. 1, 79-95. 
Vidovič Muha 1977 = Ada Vidovič Muha, Pomen pridevniške besede in njena skladenjska zveza: magistrsko delo, Ljubljana, 1977. (Tipkopis.)

Vidovič Muha 1978 = Ada Vidovič Muha, Merila pomenske delitve nezaimenske pridevniške besede, Slavistična revija 26 (1978), št. 3, 253-276.

Vidovič Muha 1981 = Ada Vidovič Muha, Pomenske skupine nekakovostnih izpeljanih pridevnikov, Slavistična revija 29 (1981), št. 1, 19-42.

Vidovič Muha 1982 = Ada Vidovič Muha, O Načrtu pravil za novi slovenski pravopis, v: Spoznanja in pripombe javne razprave o Načrtu pravil za novi pravopis, Ljubljana: Znanstveni inštitut Filozofske fakultete Univerze Edvarda Kardelja, 1982, 121-125.

Wraber 1982 = Tone Wraber, Volčin je Blagayev, ne blagayev!, v: Spoznanja in pripombe javne razprave o Načrtu pravil za novi pravopis, Ljubljana: Znanstveni inštitut Filozofske fakultete Univerze Edvarda Kardelja, 1982, 126129.

\title{
Capitalized and Non-Capitalized Slovenian Adjectives Formed from Proper Nouns with the Suffixes -ov/-ev and -in
}

\begin{abstract}
Summary
The practice of capitalizing or not capitalizing Slovenian adjectives formed from proper names with the suffixes $-o v /-e v$ and $-i n$ has been determined by tradition and material from contemporary language use ever since the first Slovenian normative guide. Initially such adjectives were exclusively capitalized, but recently there has been an increase in usage doublets in various semantic groups of such adjectives, towards which the currently valid codification and normative guide are also inclining. Not capitalizing these adjectives fosters nativization and, with this, loss of their proper-name motivation as well. This article proposes that the modern standardization of adjectives formed from proper names with the suffixes -ov/-ev and -in take into account two factors in addition to linguistic categorization: the culturological aspect of capitalization for expressions denoting special a relationship or esteem, and the pragmatic principle, which also takes into account the linguistic (lack of) knowledge of the general public during codification.
\end{abstract}

